\title{
School Support Received and the Challenges Encountered in Distance Learning Education by Filipino Teachers during the Covid-19 Pandemic
}

\author{
Angelito Palma Bautista Jr. \\ Quezon City University, Quezon City, Philippines \\ https://orcid.org/0000-0001-6591-7280 \\ Doris Gelvoligaya Bleza and Cielito Bernardino Buhain \\ Polytechnic University of the Philippines, Manila, Philippines \\ https://orcid.org/0000-0002-4314-1060 \\ https:// orcid.org/0000-0002-0633-5210 \\ Dianne Morta Balibrea \\ Blue Chips Research and Consultancy, Navotas City, Philippines \\ https://orcid.org/0000-0001-8600-8246
}

\begin{abstract}
Distance learning has become the sole modality of the teaching and learning process in the Philippines due to the Covid-19 pandemic. Since face-to-face classes are still prohibited with no end in sight, it is important to assess the experience of teachers handling distance learning education in terms of the support they have received, and the challenges encountered. This study examines the support provided by the schools, the challenges encountered by the teachers, and the support they need to thrive in distance learning education. By applying a quantitative approach through an online survey, 151 teachers - including 108 women, 41 men, and 2 respondents who did not mention their gender - served as the respondents of this study. The study derived promising results in that the majority of the respondents received adequate support from their respective schools in terms of capacity building, technical and data privacy matters, systems of information dissemination, and online learning management. Financial and emotional support mechanisms are two areas for improvement. The common problems encountered include motivating the students, using ICT, managing the time allotted for online sessions, and evaluating the learners' knowledge. The teachers were also looking for more free resources and tools, webinars to share ideas and challenges, and professional development. Overall, the respondents were confident handling remote classes during the pandemic. The Department of Education (DepEd) and the schools may devise targeted programs, training, and support mechanisms to ensure that no one in the education sector is left behind.
\end{abstract}

Keywords: Covid-19 pandemic; distance learning education; support mechanisms; challenges; capacity building 


\section{Introduction}

The global impact of Covid-19 is evident in various sectors of society including health, the economy, and education. More than a year after the first Covid-19 case was detected in Wuhan, China, more than 140 million positive Covid-19 cases and at least 3.0 million global deaths have been recorded. In the Philippines, more than 900,000 cases and 15,000 deaths have been confirmed (John Hopkins University \& Medicine, 2021).

With government agencies, private organizations, and academic institutions working hard to develop new antiviral and therapeutic solutions, minimum health standard measures have been implemented in various places to slow the spread of the virus. However, due to the quick rise in infections, many countries enforced strict quarantine and lockdown measures. In the Philippines, the government decided to impose an Enhanced Community Quarantine (ECQ) in March 2020 in many regions of the country to slow down the spread of Covid-19 and to prevent the overburdening of the health system (Panelo, 2020). This quarantine mechanism restricted most non-essential activities and movements outside the home. To date, the National Capital Region (NCR) is still under modified enhanced community quarantine (MECQ).

The education sector has been severely hit by the ongoing pandemic. When the ECQ was declared in March 2020, all schools in the Philippines were ordered to close (Medialdea, 2020). The World Health Organization (WHO) has also advised educations and students to adopt alternative learning in order to mitigate the cancellation of face-to-face classes. Since March 2020, schools in many parts of the world have been using a mixture of distance learning strategies such as online classes, printed modules, and TV/radio lessons to ensure that a learning environment is maintained where the students are located. (Asian Development Bank, 2021).

The Covid-19 pandemic has changed the education landscape. Shutting down schools globally has resulted in over 1.2 billion children being out of the classroom (Li \& Lalani, 2020). In March 2021, schools for more than 168 million children have been completely closed for almost an entire year due to the lockdowns (United Nations Children's Fund, 2021). Globally, around 214 million children have missed more than three-quarters of their face-to-face learning. As a result, e-learning rose distinctively with teaching undertaken remotely and on digital platforms.

Distance education has been promoted to address the issues related to geographical distance and the many reasons that prevent in-person learning and face-to-face classes, such as the pandemic (Kim, 2020; Singh \& Thurman 2019; Yilmaz, 2019). It is sometimes referred to as e-learning or online learning. It is an institution-based formal type of education where learners, resources, and instructors use interactive telecommunications systems to connect (Kim, 2020). Distance education can be either asynchronous, where the learning happens where the students can choose when to participate in learning using various tools, or synchronous. This is where learning occurs using a live video feed (such 
as Zoom, Google Meet or Discord) with immediate feedback from the students and teachers (Kim, 2020).

Schools in the Philippines have remained completely closed for more than a year since the pandemic has forced the government to suspend face-to-face classes. Educational institutions have been forced to transition to digital or online classrooms for the remaining months of the school year (SY) 2019 - 2020 which has continued into SY 2020 - 2021, resulting in the implementation of remote learning or distance learning where the teacher and students are essential (Almario \& Austria, 2020). Moreover, the president of the Philippines has also rejected the resumption of face-to-face classes even though Covid-19 vaccines have arrived (Galvez \& Orejas, 2021).

Different educational platforms have been used by teachers to facilitate the distance learning setup. For example, the Philippine Department of Education (DepED) developed DepED Commons, an online educational platform that supports alternative learning modalities during the extended quarantine period (Asian Development Bank, 2020). It is being used by both public and private schools to help drive the continuous delivery of basic education in the country. A Learning Continuity Plan (LCP) was also adopted by the DepED (Department of Education, 2020). Meanwhile, the Commission on Higher Education (CHED) gave higher education institutions (HEIs) the freedom to implement available distance learning, e-learning, and other alternative modes of education delivery (De Vera III, 2020). Various online platforms are being used to deliver education in new ways in the Philippines, a country that has an internet penetration rate of $67.0 \%$ and more than 73.91 million internet users (Hootsuite \& We Are Social, 2021). Zoom, Google Meet, Discord, and Microsoft Teams have become the new classrooms, while teachers take advantage of different social media sites such as Facebook and YouTube where recordings of the class lectures are uploaded.

Considering that SY 2020 - 2021 was the first year when distance learning education was implemented instead of in-school learning, it is important to understand the experience of Filipino teachers when handling distance learning in order to facilitate a better teaching experience in the coming months. Philippine educational institutions have to adapt to this changing landscape since it is inevitable that in the future, schools have to move towards a new kind of educational model that utilizes advanced technologies.

Globally, many studies have focused on the experience of students when dealing with distance learning during the Covid-19 crisis such as in Indonesia (Sutiah et al., 2020), Tanzania (Mahundu, 2020), and the Ukraine (Nenko et al., 2020). Many students have inadequate access to digital learning resources, have a limited reliable and stable internet connection (Nenko et al., 2020), and might not have sufficient resiliency and skills to learn on their own and face the challenges such as being distracted by their surroundings because of the limited hands-on activities (Sutiah et al., 2020). Moreover, while research suggests that online learning helps to increase the retention of information and takes less time ( $\mathrm{Li} \&$ Lalani, 2020). Limited internet access was found to be one of the main reasons 
why the online teaching-learning process might make it difficult to obtain a quality education (Nenko et al., 2020).

Several other studies have also revealed the problems experienced by teachers when handling distance learning classes during the pandemic. For example, in Portugal, teachers have to suddenly adapt to new pedagogies and modes of teaching with only a limited amount of time to be trained in remote instruction (Flores \& Gago, 2020). Meanwhile, a report by the Organisation for Economic Co-operation and Development (OECD) on the impact of Covid-19 on education in member countries revealed that both teachers and students have had to rely on their available personal resources to continue learning remotely during the pandemic (Schleicher, 2020). Considering these challenges, Hodges et al. (2020) stated that several elements must be assessed in order to guarantee the effectiveness of remote learning, including the faculty's professional development for online teaching pedagogies and the tools, policy, and governance issues connected to distance program development and quality assurance. The Covid-19 pandemic has challenged the academic idea of when, where, and how to deliver education, the importance of lifelong learning, and the need for learning agility and resilience in times of a crisis.

In the Philippines, a study by Arinto (2016) among the faculty and administrators at the University of the Philippines - Open University revealed that despite the interest and willingness to explore new practices and new directions in Open and Distance e-Learning (ODeL), nurturing innovative teaching and learning practices across the institution is still regarded as a challenge. Meanwhile, selected teachers from the Department of Education were found to have a positive attitude to ODeL, with the majority ready for online learning (Ventayen, 2018).

Since Covid-19 is a recent phenomenon and its impact on the education sector is relatively new, only a few studies have studied the implementation of distance education and e-learning. Reyes-Chua et al. (2020) found that students in selected HEIs in the Calabarzon region have faced problems such as a lack of resources, difficulty accessing a $\mathrm{Wi}$-Fi connection, and a lack of valuable training among both the students and faculty members. Joaquin et al. (2020) revealed that there are still gaps and challenges in terms of teacher capacity, the situation, the context of the learner, and the efficiency of the learning environment, even though innovations have been made by HEIs in the Philippines in terms of alternative learning modes and technologies for delivering education. Lapada et al. (2020) studied Covid-19 awareness, distance learning education experiences, and the perceptions of institutional readiness and the challenges found among Filipino teachers. They found that the teaching experience duration $(X 2)=$ $19.093 ; p=.001)$ and geographic location $(X 2(4)=10.973 ; p=.004)$ were very strongly correlated to the readiness to engage in distance learning education.

This study aims to describe the support provided by the schools to Filipino teachers during the Covid-19 pandemic and the implementation of distance learning. This is in addition to the challenges that the teachers have encountered 
in the past year when handling distance education classes, and the support that they need to ensure the continuous delivery of quality distance learning education. It is essential to know how the teachers have adjusted to the transition and how their schools supported them while they were adapting. The results from this study will help policymakers to formulate more relevant and adequate policies and instructions to assist the teachers in becoming better distance learning educators.

\section{Methodology}

\subsection{Research Design and Respondents}

In this descriptive research study, which aims to analyze the teachers' views about their distance learning experiences, the challenges they faced, and the support they received from their school during the Covid-19 pandemic, an online survey was adopted. This was deemed to be the most appropriate data gathering method considering the restrictions imposed during the general community quarantine, as well as the uncertainties brought about by the increasing number of positive cases around the country.

Based on the total population of teachers in the Philippines as of 2020, some $1,243,445$ according to various sources including public schools, private schools, state universities, and colleges, and private higher education institutions (Commission on Higher Education, 2020a, 2020b; Llego, 2020), the sample size was calculated using a margin of error of $8 \%$ and a confidence level of $95 \%$. The sample size was 151 respondents which included 108 women, 41 men and 2 respondents who did not mention their gender. Nearly two-thirds of the respondents (110) were regular, permanent or full-time instructors, 27 were teaching part-time, 12 were casual/contractual but full-time teachers and only 2 did not mention their type of employment. The researcher utilized a purposive sampling method in which elements were chosen from the population based on the study's objective. The inclusion criteria established by the researcher were aged 18 and above, currently teaching SY 2020 - 2021 during the Covid-19 pandemic, and able to complete the online survey.

\subsection{Survey Instrument}

Due to the ongoing quarantine measures in the country, the schools were still closed at all levels at the time that the survey was conducted. Since the researchers and respondents couldn't meet with the researcher face to face for the survey, an online survey was utilized using Google Forms. The data collection was conducted from $26^{\text {th }}$ January to $25^{\text {th }}$ February (30 days) until the desired number of responses was reached. A call for survey participation was posted on social media, primarily Facebook.

The researchers formulated the survey questionnaire on "Distance Learning Education Experience of Teachers during Covid-19" (Appendix 1). The questions were derived from various items of literature and previous studies and surveys such as from the "Questionnaires on Teachers Awareness, Readiness and Online Learning Experience During Covid-19 ECQ" by Lapada et al. (2020), the European Survey on Online and Distance Learning by the School 
Education Gateway (2020), and the Survey on Faculty Attitudes towards Online Education by Lee et al. (2015).

The questionnaire consisted of four parts: 1) the respondents' demographic profile (age bracket, sex, employment status, and educational attainment), 2) their attitude towards the school's performance regarding distance learning education, composed of 10 items; 3) the problems encountered in distance learning during the Covid-19 pandemic composed of 22 items and 4) the support needed in terms of distance learning consisting of 9 items. The instrument was validated by two academic experts with experience in distance learning education. The questionnaire was piloted to ensure the clarity of the questions. Cronbach's alpha was used to confirm the internal consistency of the questions on attitude $(a=.945)$, the problems encountered $(a=.989)$, and support needed $(a=.902)$, which showed that the scales used in this study are reliable.

The survey questionnaire also contained an informed consent form which stated that the respondents could refuse to answer any question, withdraw from the survey at any time without any harm and that all data would remain confidential and strictly adhere to the provisions of the Philippine Data Privacy Act.

\subsection{Data Analysis}

The data obtained from the respondents was exported from Google Forms into Microsoft Excel. IBM SPSS v20 was used to analyze the data. The frequencies and percentages were calculated to describe the respondents' demographic profile, attitudinal responses, distance learning experiences, problems encountered, and support needed. The Kruskal-Wallis $\mathrm{H}$ test was utilized to determine the differences between the groups for the selected demographic variables (age bracket, gender, educational attainment, employment status, and monthly income) and for the respondents' answers to the different scales. The Kruskal-Wallis $\mathrm{H}$ test is a rank-based nonparametric test that can be used to see whether two or more groups of an independent variable on a continuous scale or an ordinal dependent variable involve statistically significant differences. The statistical significance level was set at $p<0.05$.

\section{Results}

\subsection{Teachers' Demographic Characteristics}

Of the 151 respondents, $75 \%$ were women and $27 \%$ were men. In terms of educational attainment, $46 \%$ were college graduates, while $29 \%$ held postgraduate degrees. Almost two-thirds (73\%) of the respondents were regular/permanent/full-time teachers, while $18 \%$ worked part-time. Part-time faculty or part-time teachers refers to a member of the faculty who does not meet the requirements for being a full-time faculty member such as doing less than 8 hours of work a day and having no other remunerative occupation elsewhere requiring regular hours of work (DOLE-DEPED-TESDA-CHED Joint Guidelines, 2014). Half of the respondents earned Php 20,001 - Php 25,000, which is slightly higher than the Php 19,566 average monthly salary of public school teachers and the Php11,416 average monthly salary of private school teachers. Both of the 
averages were recorded in 2016 according to the Labor Force Survey (Department of Education, 2019).

Table 1: Demographic Characteristics of the Respondents

\begin{tabular}{llcc}
\hline & & f & \% \\
\hline Age Bracket & $21-25$ & 12 & 8 \\
& $26-30$ & 15 & 10 \\
& $31-35$ & 18 & 12 \\
& $36-40$ & 22 & 15 \\
& $41-45$ & 20 & 13 \\
& $46-50$ & 21 & 14 \\
& $51-55$ & 18 & 12 \\
& 56 and above & 17 & 11 \\
& No answer/Prefer not to say & 8 & 5 \\
\hline Gender & Female & 108 & 72 \\
& Male & 41 & 27 \\
& Prefer not to say & 2 & 1 \\
\hline Educational Attainment & College Level & 3 & 2 \\
& College Graduate & 70 & 46 \\
& Post-Graduate Level & 33 & 22 \\
& Post-Graduate & 45 & 29 \\
\hline Employment Status & Regular/Permanent/Full Time & 110 & 73 \\
& Casual/Contractual but Full Time & 12 & 8 \\
& Part-time & 27 & 18 \\
& No answer/Prefer not to say & 2 & 1 \\
\hline Monthly Income & Php 10,000 below & 12 & 8 \\
& Php 10,001 - Php 15,000 & 12 & 8 \\
& Php 15,001 - Php 20,000 & 10 & 7 \\
& Php 20,001- Php 25,000 & 51 & 34 \\
& Php 25,001 - Php 30,000 & 26 & 17 \\
& Php 30,001 - Php 35,000 & 5 & 3 \\
& Php 35,001 above & 21 & 14 \\
& Prefer not to say & 14 & 9 \\
\hline & & & 151 \\
\hline
\end{tabular}

In terms of teaching experience, $25 \%$ had been teaching for more than 21 years, $20 \%$ had been working for $6-10$ years, and another $20 \%$ had been working for 11 - 15 years. When it comes to online teaching, a majority $(61 \%)$ said that this was their first experience of online teaching while $20 \%$ had some experience.

The majority of the respondents were teaching at the college $(37 \%)$ and elementary (35\%) levels, followed by senior high school $(21 \%)$ and junior high school $(17 \%)$. More than half of them were teaching in public schools $(58 \%)$, while $27 \%$ are from state universities and colleges. Only 15\% were from private education institutions (sectarian and non-sectarian). When asked how confident they were teaching remotely during the pandemic, 33\% had a neutral feeling, $32 \%$ said they were somehow confident, $17 \%$ were somehow not confident, while $15 \%$ were very confident. Only $2 \%$ of the respondents said that they were not at all confident. In general, the respondents of this study are confident when it comes to handling remote classes. 
Table 2: Teaching experience of the respondents

\begin{tabular}{|c|c|c|c|}
\hline & & $\mathbf{f}$ & $\%$ \\
\hline \multirow{7}{*}{$\begin{array}{l}\text { Length of experience as } \\
\text { a teacher }\end{array}$} & 2 years and below & 14 & 9 \\
\hline & $3-5$ years & 28 & 19 \\
\hline & $6-10$ years & 30 & 20 \\
\hline & 11 - 15 years & 30 & 20 \\
\hline & 16 - 20 years & 11 & 7 \\
\hline & 21 years and above & 37 & 25 \\
\hline & Prefer not to say & 1 & 1 \\
\hline \multirow[t]{4}{*}{$\begin{array}{l}\text { Experience of Online } \\
\text { Teaching }\end{array}$} & $\begin{array}{l}\text { I have extensive experience with online } \\
\text { teaching }\end{array}$ & 19 & 13 \\
\hline & I have some experience with online teaching & 30 & 20 \\
\hline & This is my first experience with online teaching & 92 & 61 \\
\hline & $\begin{array}{l}\text { My school has not switched to online/distance } \\
\text { learning }\end{array}$ & 10 & 7 \\
\hline \multirow{6}{*}{$\begin{array}{l}\text { Confidence when } \\
\text { teaching remotely } \\
\text { during the pandemic }\end{array}$} & Very confident & 23 & 15 \\
\hline & Somehow confident & 48 & 32 \\
\hline & Neutral & 49 & 33 \\
\hline & Somehow not confident & 25 & 17 \\
\hline & Not at all confident & 3 & 2 \\
\hline & No answer & 3 & 2 \\
\hline Level of Education & Elementary & 53 & 35 \\
\hline \multirow[t]{6}{*}{ Teaching* } & Junior High School & 26 & 17 \\
\hline & Senior High School & 32 & 21 \\
\hline & College & 56 & 37 \\
\hline & Graduate Program & 10 & 7 \\
\hline & Others & 4 & 3 \\
\hline & No answer & 1 & 1 \\
\hline \multirow{5}{*}{$\begin{array}{l}\text { Type of School } \\
\text { Teaching* }\end{array}$} & Public School & 87 & 58 \\
\hline & Private Sectarian & 9 & 6 \\
\hline & Private Non-sectarian & 14 & 9 \\
\hline & State Universities and Colleges & 41 & 27 \\
\hline & Local Colleges and Universities & 5 & 3 \\
\hline
\end{tabular}

$N=151$. *Multiple response questions. Note: Due to rounding off, the sum of the percentage may not total to 100 or may exceed 100

\subsection{Distance Learning Support Provided by the Schools}

The respondents were asked to rate the support provided by their schools in terms of distance learning during the Covid-19 pandemic. The majority (53\%) of the respondents strongly believe that their schools have regulations and policies on the use of distance learning to protect the student's identity and data privacy $(M=3.45, S D=0.587)$. Likewise, $44 \%$ strongly agree that the school has provided a technical support system to the teachers $(M=3.32, \mathrm{SD}=0.698), 40 \%$ strongly agree that a system of information dissemination to communicate with both parents and learners has been provided $(M=3.32, S D=0.617)$, and $40 \%$ strongly agreed when asked that the school has procured an online learning management system $(M=3.26, S D=0.725)$. A total of $27 \%$ of the respondents disagreed when they were asked if their school had a financial support system $(M=2.92, S D=0.772)$, and $20 \%$ said that their schools did not provide an emotional support system mechanism for the teachers $(M=3.05, S D=0.769)$. 
There were also a notable number of respondents who said that their schools did not provide supplementary materials for distance learning $(M=3.10, S D=$ $0.758)$, as well as a designated workforce for Covid-19 $(M=3.25, S D=.685)$. The calculated standard deviations show that the results for each statement are relatively near to the data set's mean.

Table 3: Distance learning support provided by the schools

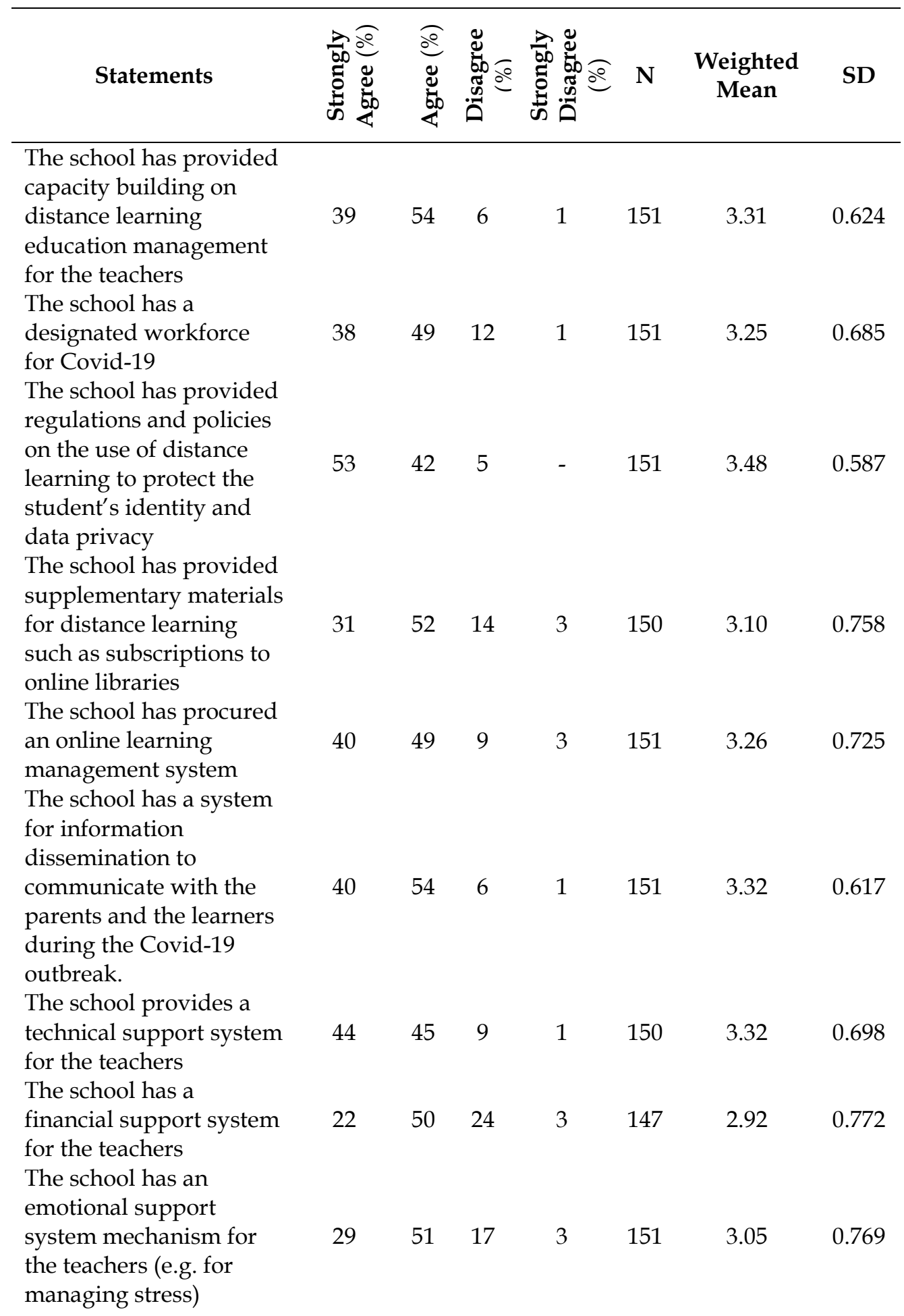


The school has provided a positive environment for teachings during the 34 $54 \quad 11$ 2 149 3.19 0.701 crisis

Note: Due to rounding off, the sum of the percentages may not total to 100 or may exceed 100

\subsection{Problems Encountered when Distance Learning during the Pandemic}

Based on their responses, the most frequent problem (every time) they encountered was motivating the students (35\%), using information and communication technologies (32\%), managing the time allotted for the online sessions or teaching hours (32\%), and evaluating the learner's knowledge (30\%). All of the given problems were usually encountered (about $90 \%$ of the time) by more than $35 \%$ of the respondents, most notably interacting/communicating with the students $(47 \%)$, meeting the learning outcomes determined for the students (47\%), and converting activities and content into those suitable for online/distance learning (46\%). It is important to note that all of the given problems were experienced by the majority of the respondents for at least $50 \%$ of the time, at least a few months before the end of the school year.

Table 4: Problems encountered in distance learning education

\begin{tabular}{|c|c|c|c|c|c|c|c|}
\hline Statements & $\begin{array}{l}\text { Every } \\
\text { time } \\
(\%)\end{array}$ & $\begin{array}{l}\text { Usually, in } \\
\text { about } 90 \% \\
\text { of the } \\
\text { chances, I } \\
\text { could have } \\
(\%)\end{array}$ & $\begin{array}{c}\text { Frequently, } \\
\text { in about } \\
70 \% \text { of the } \\
\text { chances } \\
\text { when I } \\
\text { could have } \\
(\%)\end{array}$ & $\begin{array}{c}\text { Sometimes, } \\
\text { in about } \\
50 \% \text { of the } \\
\text { chances } \\
\text { when I } \\
\text { could have } \\
(\%)\end{array}$ & $\begin{array}{c}\text { Occasionall } \\
\mathbf{y}, \text { in about } \\
30 \% \text { of the } \\
\text { chances } \\
\text { when I } \\
\text { could have } \\
(\%)\end{array}$ & $\begin{array}{l}\text { Rarely, in } \\
\text { less than } \\
10 \% \text { of the } \\
\text { chances } \\
\text { when I } \\
\text { could have } \\
(\%)\end{array}$ & $\begin{array}{c}\text { Never } \\
(\%)\end{array}$ \\
\hline $\begin{array}{l}\text { Access to a stable } \\
\text { internet connection }\end{array}$ & 19 & 44 & 23 & 8 & 3 & 3 & 1 \\
\hline $\begin{array}{l}\text { Teachers' access to } \\
\text { technology }\end{array}$ & 26 & 41 & 19 & 7 & 3 & 3 & 1 \\
\hline $\begin{array}{l}\text { Adapting to the } \\
\text { distance learning } \\
\text { teaching/learning } \\
\text { practices }\end{array}$ & 29 & 40 & 19 & 5 & 4 & 2 & - \\
\hline $\begin{array}{l}\text { Using information and } \\
\text { communication } \\
\text { technologies }\end{array}$ & 32 & 40 & 17 & 5 & 2 & 3 & - \\
\hline $\begin{array}{l}\text { Using the school's } \\
\text { learning management } \\
\text { system (LMS) }\end{array}$ & 27 & 36 & 22 & 8 & 3 & 3 & 1 \\
\hline $\begin{array}{l}\text { Interacting/communic } \\
\text { ating with the } \\
\text { students }\end{array}$ & 25 & 47 & 15 & 7 & 5 & 2 & - \\
\hline $\begin{array}{l}\text { Involving students } \\
\text { from socially } \\
\text { disadvantaged homes }\end{array}$ & 20 & 42 & 21 & 11 & 4 & 1 & 1 \\
\hline $\begin{array}{l}\text { Evaluating the } \\
\text { learners' knowledge } \\
\text { and skills }\end{array}$ & 30 & 36 & 20 & 10 & 2 & 2 & - \\
\hline $\begin{array}{l}\text { Providing skills } \\
\text { teaching (such as }\end{array}$ & 21 & 44 & 21 & 7 & 5 & 3 & - \\
\hline
\end{tabular}


listening or speaking

in language classes,

drawing in visual arts

lessons etc.)

Meeting the learning outcomes determined

for the students

Giving feedback to the students

Teaching according to the individual interests and abilities

of the students

Motivating the students

Managing the time allotted for the online sessions (teaching

hours)

Too many online sessions

Having a suitable environment at home

for online teaching

Communicating with parents/guardians

Students' access to technology

Little direction or support given by the

school

Converting activities and content into those suitable for

learning

Preparing content for online / distance

learning

Supporting the students with special

Note: Due to rounding off, the sum of the percentages may not total to 100 or may exceed 100

\subsection{Support Needed by the Teachers}

In terms of the support needed, 6 out of the 10 respondents $(61 \%)$ strongly agree that they need more free resources and tools from education technology companies or organizations, followed by webinars for the teachers to share ideas 
and challenges (58\%), professional development such as quick courses on online teaching $(56 \%)$, easy contact with experts in online learning $(55 \%)$, and lesson plans for good practice (55\%). Out of the 9 statements, the statement that received the highest "disagree" rating was "clear guidance from the Department of Education."

Table 5: Support needed in distance learning education

\begin{tabular}{|c|c|c|c|c|c|c|c|}
\hline Statements & $\begin{array}{l}\text { Strongly } \\
\text { Agree } \\
(\%)\end{array}$ & $\begin{array}{c}\text { Agree } \\
(\%)\end{array}$ & $\begin{array}{l}\text { Disagree } \\
\quad(\%)\end{array}$ & $\begin{array}{l}\text { Strongly } \\
\text { Disagree } \\
(\%)\end{array}$ & $\mathbf{N}$ & $\begin{array}{l}\text { Weighted } \\
\text { Mean }\end{array}$ & SD \\
\hline $\begin{array}{l}\text { Professional development: } \\
\text { quick courses on online } \\
\text { teaching }\end{array}$ & 56 & 43 & 1 & - & 148 & 3.55 & 0.526 \\
\hline $\begin{array}{l}\text { Easy contact with experts } \\
\text { (e.g. experienced online- } \\
\text { learning teachers and ICT } \\
\text { experts) }\end{array}$ & 55 & 42 & 3 & 1 & 149 & 3.51 & 0.588 \\
\hline $\begin{array}{l}\text { Clear guidance from the } \\
\text { Department of Education }\end{array}$ & 53 & 38 & 9 & - & 149 & 3.44 & 0.661 \\
\hline $\begin{array}{l}\text { Websites with lists of useful } \\
\text { resources }\end{array}$ & 53 & 44 & 3 & - & 149 & 3.50 & 0.565 \\
\hline Video clips of good practices & 54 & 44 & 3 & - & 149 & 3.51 & 0.553 \\
\hline $\begin{array}{l}\text { Lesson plans on good } \\
\text { practices }\end{array}$ & 55 & 45 & 1 & - & 148 & 3.54 & 0.513 \\
\hline $\begin{array}{l}\text { More educational TV } \\
\text { programs made by national } \\
\text { media organizations }\end{array}$ & 52 & 44 & 4 & - & 148 & 3.48 & 0.577 \\
\hline $\begin{array}{l}\text { More free resources and tools } \\
\text { from education technology } \\
\text { companies or organizations }\end{array}$ & 61 & 37 & 2 & - & 149 & 3.59 & 0.533 \\
\hline $\begin{array}{l}\text { Webinars for the teachers to } \\
\text { share ideas and challenges }\end{array}$ & 58 & 41 & 1 & - & 149 & 3.58 & 0.509 \\
\hline
\end{tabular}

Note: Due to rounding off, the sum of the percentages may not total to 100 or may exceed 100

3.5 Significant Differences between the Demographic Characteristics of the Respondents and the Distance Learning Support provided by the Schools, the Problems Encountered by the Teachers, and the Support Needed by the Teachers in Distance Learning Education

The Kruskal-Wallis test was used to examine the differences in the distance learning support provided by the schools, the problems encountered by the teachers, and the support needed according to the respondents' age bracket, gender, educational attainment, employment status, and monthly income (Table 6). The test showed that there was no statistically significant difference found in the distance learning support provided by the schools as rated by the respondents and their demographic characteristics. There were also no statistically significant differences found in the problems experienced by the teachers and their demographic characteristics. 
Meanwhile, there was a statistically significant difference found in the support needed by the teachers and their age bracket, $H(3)=21.471, p=.006$. Those who were older were more likely to give seek support than those who were younger, as shown in the mean ranks in Table 7.

Table 6: Results of the Kruskal-Wallis test

\begin{tabular}{|c|c|c|c|c|c|c|}
\hline & & $\begin{array}{c}\text { Age } \\
\text { Bracket }\end{array}$ & Gender & $\begin{array}{l}\text { Educational } \\
\text { Attainment }\end{array}$ & $\begin{array}{l}\text { Employment } \\
\text { Status }\end{array}$ & $\begin{array}{l}\text { Monthly } \\
\text { Income }\end{array}$ \\
\hline \multirow{3}{*}{$\begin{array}{l}\text { Support } \\
\text { provided by the } \\
\text { schools }\end{array}$} & $\chi^{2}(2)$ & 12.751 & 0.060 & 1.829 & 7.649 & 13.231 \\
\hline & $\mathrm{df}$ & 8 & 1 & 2 & 3 & 7 \\
\hline & $\mathrm{p}$-value & . 121 & .806 & .401 & .054 & .067 \\
\hline \multirow{3}{*}{$\begin{array}{l}\text { Problems } \\
\text { encountered by } \\
\text { the teachers }\end{array}$} & $X^{2}(2)$ & 3.981 & 2.068 & 0.595 & 6.160 & 5.986 \\
\hline & $\mathrm{df}$ & 8 & 1 & 2 & 2 & 7 \\
\hline & $\mathrm{p}$-value & .859 & .150 & .743 & .104 & .541 \\
\hline \multirow{3}{*}{$\begin{array}{l}\text { Support needed } \\
\text { by the teachers }\end{array}$} & $\chi^{2}(2)$ & 21.471 & 0.020 & 5.368 & 1.511 & 13.447 \\
\hline & $\mathrm{df}$ & 8 & 1 & 2 & 3 & 7 \\
\hline & $\mathrm{p}$-value & .006 & .888 & .068 & .680 & .062 \\
\hline
\end{tabular}

Table 7: Mean ranks per age bracket according to the support needed by the teachers

\begin{tabular}{lcc}
\hline Age Bracket & f & Mean Rank \\
\hline $21-25$ & 12 & 43.67 \\
$26-30$ & 14 & 78.57 \\
$31-35$ & 18 & 51.50 \\
$36-40$ & 22 & 77.86 \\
$41-45$ & 20 & 78.75 \\
$46-50$ & 21 & 75.43 \\
$51-55$ & 18 & 84.94 \\
56 and above & 16 & 82.03 \\
No answer/Prefer not to say & 8 & 113.81 \\
\hline
\end{tabular}

3.6 Significant Differences between the Teaching Experience of the Respondents and the Distance Learning Support provided by the Schools, the Problems Encountered by the Teachers, and the Support Needed by the Teachers in Distance Learning Education

The Kruskal-Wallis test also found that there was no statistically significant difference between the distance learning support provided by the schools, the problems encountered by the teachers, the support needed by the teachers in distance learning education, and the respondents' length of experience as a teacher, in addition to their length of experience doing online teaching. 
Table 8: Results of the Kruskal-Wallis test

\begin{tabular}{llcc}
\hline & & $\begin{array}{c}\text { Length of Experience } \\
\text { as a Teacher }\end{array}$ & $\begin{array}{c}\text { Length of Experience } \\
\text { when Online } \\
\text { Teaching }\end{array}$ \\
\hline Support provided & $\mathrm{X}^{2}(2)$ & 9.891 & 7.204 \\
by the schools & $\mathrm{Df}$ & 6 & 3 \\
& $\mathrm{p}$-value & .129 & .066 \\
\hline Problems & $\mathrm{X}^{2}(2)$ & 3.340 & 3.579 \\
encountered by & $\mathrm{Df}$ & 6 & 3 \\
the teachers & $\mathrm{p}$-value & .765 & .311 \\
\hline Support needed & $\mathrm{X}^{2}(2)$ & 5.892 & 2.950 \\
by the teachers & $\mathrm{Df}$ & 6 & 3 \\
& $\mathrm{p}$-value & .435 & .399 \\
\hline
\end{tabular}

\section{Discussion}

This study is an attempt to shed light on the experiences of Filipino teachers when handling distance learning classes during the Covid-19 pandemic, specifically the support provided by the schools, the problems that they encountered when handling distance learning education classes, and the support they need to continue providing quality distance learning education to their students. It has been more than a year since the schools in the country were closed, and the teachers and students were forced to adopt distance learning to cope with the changes brought about by the pandemic. Because of this, it is pertinent that the teachers are heard, and their experience is known in order to meet the growing demands and challenges of distance learning.

Six out of 10 respondent teachers said that it was their first experience with online teaching during the Covid-19 pandemic. Only 33\% of the respondents had some previous experience with online teaching. A closer look at the data reveals that the "first-timers" were comprised of both experienced (more than 10 years teaching experience) and less experienced teachers (between 1 - 5 years of experience). Regardless of their teaching experience, many of the respondents did not have enough experience handling distance learning education. This result is similar to the study conducted by the School Education Gateway (2020) in Europe at the beginning of the pandemic which showed that $66.9 \%$ of teachers confirmed that they were using or had used online platforms for teaching for the first time.

The majority of the respondents strongly agreed that they receive varied support from their schools, specifically in terms of the policies to protect data privacy, systems of information dissemination for communicating with both parents and learners, and the technical support systems provided to the teachers. The switch to distance learning, specifically online education, brings with it security and privacy challenges which may cause substantial big data threats that may affect the lives of both the teachers and students (Çubukçu \& Aktürk, 2020). In September 2020, the Data Privacy Council Education Sector of the Philippines released Advisory No. 2020-1. This contains the guidelines to help teachers, parents, students, and school administrators safely navigate digital spaces. It 
also provides clear guidance on how to protect data in the conducting of online learning. Notably, the teachers have been receiving policy support in terms of this valuable matter.

Furthermore, it should be noted that almost half of the respondents were confident when teaching remotely $32 \%$ somehow confident and $15 \%$ very confident). The previous studies found there to be a positive correlation between the teachers' levels of self-efficacy and the student's achievements and motivation, as well as the teachers' wellbeing (Zee \& Koomen, 2016). The teachers who have more confidence in their capacity to effectively teach remotely are more likely to create a more productive and high-quality learning environment. This research has highlighted the importance of school support in increasing the level of confidence of the teachers, and ensuring their wellbeing (Müller \& Goldenberg, 2020).

Another key finding is the higher number of teachers, albeit not the majority, who said that they were not provided with financial and emotional support mechanisms. Filipino teachers do not have high salaries, which can be as low as Php 8,000 in some private schools, while public school teachers face demands that are far from reasonable in contrast to their monthly wage (Tagupa, 2018). Even with distance learning, the teachers will need to spend money to buy the needed technology and pay for the internet services to continue working in a distance learning setting. Monetary assistance provided by the schools may help the teachers to buy equipment and materials for the technology to support distance learning. Meanwhile, emotional support is also needed as the teachers are overworked and face more stress dealing with new technologies and handling online classes that are not within their expertise. In the US, a 2020 distance learning survey conducted by Panorama revealed that more than $20 \%$ of around 13,000 educators in the country were concerned about their mental wellbeing (Paykamian, 2021). Filipino teachers will need more emotional support during the crisis, especially as many of them are facing a very unique and new dilemma when handling distance learning classes.

One problem encountered in distance learning is motivating the students. This has also been found in the previous studies such as those conducted in Turkey and the Philippines (Korkmaz \& Toraman, 2020; Lapada et al., 2020). For this reason, Filipino teachers have to devise ways to ensure that the students engaged in distance education are motivated, especially that there is still uncertainty when in-school learning will return due to the pandemic. Limited internet access plays a major part in why the online teaching-learning process might hinder the acquisition of quality education (Nenko et al., 2020). The results of this survey prove that motivating the students and access to technology among the teachers can make the process more difficult. The other problems identified were also found in the previous studies, specifically the problems regarding facilities, equipment, and capacity building (Joshi et al., 2020; Lapada et al., 2020). 
The support provided by the schools and the problems encountered by the teachers were not found to be associated with the demographic characteristics of the respondents, specifically their age bracket, gender, educational attainment, employment status, and monthly income. However, the study found out that there is a statistically significant difference between the support needed by teachers and their age bracket. Older teachers need more assistance or support navigating distance learning education. Although the number of years of teaching experience was not found to be associated with any of the variables in the study, unlike the previous studies such as the one conducted by Lapada et al. (2020), the association between age and the support needed may still support the notion that the older respondents with a longer teaching experience are relatively less tech-savvy.

Unsurprisingly, the teachers need the most support in terms of resources and tools, webinars to share ideas and challenges, professional development programs, and easy contact with experts in online learning. The results are supported by the earlier study by the School Education Gateway (2020) in Europe where free resources from education technology companies, professional development such as quick courses on online teaching, and webinars for teachers to share ideas, and easy contact with experts were also mentioned as a necessary support to aid in the implementation of effective distance learning education. These support mechanisms are needed to address the problems encountered by the respondents. As Hodges et al. (2020) noted, online learning and teaching will only be effective if the teachers can acquire the appropriate competencies and possess the right attitude towards their professional development.

\section{Limitations}

The study has several limitations that future researchers must consider. First, selecting the respondents was done using purposive sampling through the network of the researchers on Facebook. This resulted in a low number of respondents. There may be the presence of bias against other members of the teaching population in terms of geography and the type of school. Future researchers may also consider studying the attitude of the teachers towards distance learning education, as well as differentiating between the attitude and problems experienced by teachers in terms of the type of remote learning.

\section{Conclusion}

This research aims to shed light on the Filipino teachers' experiences with distance learning classes during the Covid-19 pandemic, specifically the support provided by their schools, the challenges that they faced when handling distance learning classes, and the support that they require to continue providing quality distance learning education to their students. In total, 151 teachers participated in this study which employed a quantitative approach through an online survey.

The changes faced by the teachers in terms of their teaching practices during the pandemic are abrupt. The Filipino teachers who were part of this study revealed that they received adequate support from their respective schools, although 
problems remained in terms of infrastructure, the teachers' competency especially in ICT, professional development, handling the students in an online environment, and meeting the goals laid out in the lesson plans and curriculum of the respective subjects that they are teaching. However, despite these problems, it is encouraging to note that the respondents were confident when handling remote classes during the pandemic. Since the return to in-school learning is still in limbo due to the continuous threat of Covid-19, the Filipino teachers were able to adapt to the new ways of working in a distance learning environment.

\section{Recommendations}

Since there are differences between the support needed by the teachers according to their age bracket, the Department of Education (DepEd) and the need for the schools to devise targeted programs, training, and support mechanisms to ensure that no one in the education sector is left behind. Designated IT experts must be assigned to assist the teachers such as when handling online classes or preparing video presentations for asynchronous learning. Likewise, since the teachers are having difficulty meeting the goals of the lessons and managing the time allocated for their classes, the DepEd may consider restructuring the course syllabus to meet their specific needs. It will also be helpful for the existing policies concerning data privacy and protecting the students' identity in an online environment to be localized, cascaded at the school levels. The schools may consider appointing data privacy point persons that will help the teachers understand and successfully implement data privacy policies and regulations.

\section{References}

Almario, A. R., \& Austria, R. (2020). Helping K-12 schools transition to post-COVID 19 times. https://authdocs.deped.gov.ph/wp-content/uploads/2020/06/BE-LCPAnnex-E-Ani-Almario-Helping-K-12-Schools-Transition-to-Post-COVID.pdf

Arinto, P. B. (2016). Issues and challenges in open and distance e-learning: perspectives from the Philippines. The International Review of Research in Open and Distributed Learning, 17(2). https://doi.org/10.19173/irrodl.v17i2.1913

Asian Development Bank. (2021). COVID-19 and education in Asia and the Pacific guidance note. https://www.adb.org/sites/default/files/institutionaldocument/672491/covid-19-education-asia-pacific-guidance-note.pdf

Commission on Higher Education. (2020a). State universities and colleges number of faculty by program level. 2020 Higher Education Facts and Figures. https://ched.gov.ph/wp-content/uploads/State-Universities-and-CollegesNumber-of-Faculty-by-Program-Level-AY-2019-20.pdf

Commission on Higher Education. (2020b). Private higher education institutions number of faculty by program level. 2020 Higher Education Facts and Figures. https://ched.gov.ph/wp-content/uploads/Private-Higher-EducationInstitutions-Number-of-Faculty-by-Program-Level-AY-2019-20.pdf

Çubukçu, C., \& Aktürk, C. (2020). The rise of distance education during Covid-19 Pandemic and the related data threats: A study about Zoom. Igdir University Social https://www.researchgate.net/publication/344726977_The_Rise_of_Distance_E ducation_during_Covid- 
19_Pandemic_and_the_Related_Data_Threats_A_Study_about_Zoom_Igdir_Uni versity_Social_Sciences_Journal/citation/download

Data Privacy Council Education Sector. (2020). Advisory No. 2020-1: Data privacy and online learning. https://www.privacy.gov.ph/wpcontent/uploads/2020/10/DP-Council-Education-Sector-Advisory-No.-20201.pdf

Department of Education. (2020). Towards a sustainable and working DepEd commons part II: A framework. https://commons.deped.gov.ph/deped-commons-framework.pdf

Department of Education. (2019). Average monthly salaries of teachers. [PowerPoint slides]. https://www.deped.gov.ph/wp-content/uploads/2019/06/Tables-SLMBSalaries-statement.pptx

De Vera III, P. (2020, Sept 02). CHED Memorandum Order No. 04: Guidelines on the implementation of flexible learning. https://ched.gov.ph/wpcontent/uploads/CMO-No.-4-s.-2020-Guidelines-on-the-Implementation-ofFlexible-Learning.pdf

DOLE-DEPED-TESDA-CHED Joint Guidelines. (2014, May 30). Joint guidelines on the implementation of the labor and management component of Republic Act No. 10533 (Enhanced Basic Education Act of 2013). http://www.pacu.org.ph/wordpress/wp-content/uploads/2017/03/DOLEDEPED-TESDA-CHED-Joint-Guidelines-on-K-to-12.pdf

Flores, M. A., \& Gago, M. (2020). Teacher education in times of COVID-19 pandemic in Portugal: national, institutional and pedagogical responses. Journal of Education for Teaching, 46(4), 507-516. http:/ / doi.org/10.1080/02607476.2020.1799709

Hodges, C., Moore, S., Lockee, B., Trust, T., \& Bond, A. (2020, March 27). The difference between emergency remote teaching and online learning. EDUCAUSE Review. https://er.educause.edu/articles/2020/3/the-difference-between-emergencyremote-teaching-and-online-learning

Hootsuite \& We Are Social. (2021, February 11). Digital 2021: The Philippines. https:// datareportal.com/reports/digital-2021-philippines?rq=philippines

Joaquin, J. J. B., Biana, H. T., \& Dacela, M. A. (2020). The Philippine Higher Education Sector in the Time of COVID-19. Frontiers in Education, 5:576371. https://doi.org/10.3389/feduc.2020.576371

John Hopkins University. (2021). COVID-19 Map. https://coronavirus.jhu.edu/map.html

Joshi, A., Vinay, M., \& Bhaskar, P. (2020). Online teaching amidst COVID-19 in India: An outlook. Asian Journal of Distance Education, 15(2), 105-111. https://asianjde.org/ojs/index.php/AsianJDE/article/view/454

Kim, J. (2020). Learning and teaching online during COVID-19: Experiences of student teachers in an early childhood education practicum. IJEC 52, 145-158. https://doi.org/10.1007/s13158-020-00272-6

Korkmaz, G., \& Toraman, Ç. (2020). Are we ready for the post-covid-19 educational practice? An investigation into what educators think as to online learning. International Journal of Technology in Education and Science, 4(4), 293-309. https:// doi.org/10.46328/ijtes.v4i4.110

Lapada, A. A., Miguel, F. F., Robledo, D. A., \& Alam, Z. F. (2020). Teachers' COVID-19 awareness, distance learning education experiences, and perceptions towards institutional readiness and challenges. International Journal of Learning, Teaching and Educational Research, 19(6), 127-144. https://doi.org/10.26803/ijlter.19.6.8

Lee, J., March, L., \& Peters, R. (2015). Faculty training and approach to online education, is there a connection? American University, Center for Teaching, Research \& Learning. https://edspace.american.edu/online/wp- 
content/uploads/sites/504/2016/03/FacultyTrainingAndApproachToOnlineE ducation.pdf

Li, C., \& Lalani, F. (2020, April 29). The COVID-19 pandemic has changed education forever. This is how. World Economic Forum. https://www.weforum.org/agenda/2020/04/coronavirus-education-globalcovid19-online-digital-learning

Llego, M. A. (2021, April 9). DepEd Basic Education Statistics for School Year 2019-2020. TeacherPH.com. https://www.teacherph.com/deped-basic-education-statisticsschool-year-2019-2020

Mahundu, G. F. (2020). COVID-19 disease pandemic lockdown: schools closure and students e-learning options in Tanzania. SSRN. http://dx.doi.org/10.2139/ssrn.3698554

Medialdea, E. (2020, March 16). Memorandum from the Executive Secretary: Community quarantine over the entire Luzon and further guidelines for the management of the coronavirus disease 2019 (COVID-19) situation. https://www.officialgazette.gov.ph/downloads/2020/03mar/20200316MEMORANDUM-FROM-ES-RRD.pdf

Müller, L. M., \& Goldenberg, G. (2020). Education in times of crisis: The potential implications of school closures for teachers and students. Chartered College of Teaching. https:// my.chartered.college/wpcontent/uploads/2020/05/CCTReport070520_FINAL.pdf

Nenko, Y., Kybalna, N., \& Snisarenko, Y. (2020). The COVID-19 distance learning: Insight from Ukrainian students. The Brazilian Scientific Journal of Rural Education. http:/ / dx.doi.org/10.20873/uft.rbec.e8925

Galvez, D., \& Orejas, T. (2021, March 1). Duterte still won't allow in-person classes despite delivery of COVID-19 vaccines. INQUIRER.net. https:// newsinfo.inquirer.net/1401105/duterte-still-rejects-resumption-offaceface-classes

Panelo, S. S. (2020, March 12). On code red sublevel 2 -Presidential Communications Operations Office. Office of the Presidential Spokesperson. https://pcoo.gov.ph/OPS-content/on-code-red-sublevel-

Paykamian, B. (2021, March 10). Remote learning taking a toll on teacher health, morale. Government Technology. https://www.govtech.com/education/k-12/WhyTeachers-Need-Emotional-Support-During-Virtual-Learning.html

Reyes-Chua, E., Sibbaluca, B. G., Miranda, R. D., Palmario, G. B., Moreno, R. P., \& Solon, J. P. T. (2020). The Status of the Implementation of the E-learning Classroom in selected Higher Education Institutions in Region IV-A amidst the COVID-19 crisis. Journal of Critical Reviews, 7(11). https://doi.org/10.31838/jcr.07.11.41

Schleicher, A. (2020). The impact of COVID-19 on education: Insights from education at a glance 2020. OECD. https://www.gcedclearinghouse.org/resources/impactcovid-19-education-insights-education-glance-2020

School Education Gateway. (2020, August 6). Survey on online and distance learning Results.

https://www.schooleducationgateway.eu/en/pub/viewpoints/surveys/surve y-on-online-teaching.htm

Singh, V., \& Thurman, A. (2019). How many ways can we define online learning? A systematic literature review of definitions of online learning (1988-2018). American Journal of Distance Education, 33(4), 289-306. https:// doi.org/10.1080/08923647.2019.1663082

Sutiah, S., Slamet, S., Shafqat, A., \& Supriyono, S. (2020). Implementation of distance learning during the covid-19 pandemic in faculty of education and teacher 
training. Cypriot Journal of Educational Sciences, 15(5), 1204-1214. https://doi.org/10.18844/cjes.v15i5.5151

Tagupa, H. (2018, June 29). Are PH teachers really underpaid? INQUIRER.net. https://opinion.inquirer.net/114243/ph-teachers-really-underpaid

United Nations Children's Fund. (2021, March 24). COVID-19: Schools for more than 168 million. https://www.unicef.org/india/press-releases/covid-19-schools-more168-million-children-globally-have-been-completely-closed

Ventayen, R. J. M. (2018). Level of competency in computer systems servicing of teachers in one town in Northern Luzon: A needs assessment and analysis. Asian Journal of Multidisciplinary Research Studies. http://dx.doi.org/10.2139/ssrn.3153248

Yilmaz, A. B. (2019). Distance and face-to-face students' perceptions towards distance education: A comparative metaphorical study. Turkish Online Journal of Distance Education, 20(1), 1302-6488. https:// doi.org/10.17718/tojde.522705

Zee, M., \& Koomen, H. M. (2016). Teacher self-efficacy and its effects on classroom processes, student academic adjustment, and teacher well-being. Review of Educational Research, 86(4), 981-1015. https://doi.org/10.3102/0034654315626801 


\section{Appendix 1. Survey Instrument}

\section{SCHOOL SUPPORT RECEIVED AND CHALLENGES ENCOUNTERED IN DISTANCE LEARNING EDUCATION BY FILIPINO TEACHERS DURING THE COVID-19 PANDEMIC}

\section{Beloved Teachers,}

Good day!

The current situation is unprecedented. The novel coronavirus has affected millions of people around the world. In the Philippines, community quarantines were imposed since March last year to control the spread of the virus. The pandemic affected the entire education system, forcing schools to transition from in-person to online and remote classes.

Against this background, Blue Chips Research and Consultancy Co. is surveying teachers regarding their distance learning education experiences during this pandemic. In line with this, we would like to invite you to participate in this online survey. Answering this survey is voluntary. Even if you do not participate, there will be no disadvantages for you.

Before answering the survey questionnaire, please read the following information. Thank you very much in advance for your support in this endeavor!

I. Demographic Profile

Are you currently employed as a teacher/instructor (full-time or part-time) in any educational institution in the Philippines?

(This survey is for Filipino teachers/instructors teaching in any educational institution in the Philippines and are handling classes this Academic Year 2020-2021.)

Yes

(End of Survey)

Instruction: Put a mark on the space corresponding to your answer.

1. Gender

$$
\begin{array}{ll}
- & \text { Male } \\
- & \text { Female } \\
- & \text { Transgender } \\
& \text { Prefer not to say }
\end{array}
$$

2. Age Bracket

$18-20$
$-21-25$
$26-30$
$-31-35$
$-36-40$
$41-45$

\begin{tabular}{l}
$46-50$ \\
\hline $51-55$ \\
$56-60$ \\
$61-65$ \\
66 above \\
\hline
\end{tabular}


3. Educational Attainment

Elementary Level

Elementary Graduate

High School Level

High School Graduate

College Level

College Graduate

Post-Graduate Level

Post-Graduate

Vocational

Did not attend school

Prefer not to say

4. Religion

$\begin{array}{ll} & \text { Roman Catholic } \\ \text { Protestant } \\ \text { Methodist } \\ \text { Muslim } \\ \text { Iglesia ni Cristo } \\ \text { Jehova's Witnesses }\end{array}$

Evangelical

Sevent-day Adventist

Hindi ko nais sabihin

None

Others, please specify:

5. Please indicate the province where you are currently residing.

6. Please indicate the province where you are currently teaching.

7. Please indicate the school where you are currently teaching.

8. What is your employment status as a teacher?

_ Regular/Permanent/Full-Time

Casual/Contractual but Full-Time

Part-time

Special Lecturer

Prefer not to say

9. Monthly income

Php5,000 below

Php5,001 - Php10,000

Php10,001 - Php15,000

Php15,001 - Php20,000

Prefer not to say

Php20,001 - Php25,000

_ Php25,001 - Php30,000

Php30,000 - Php35,000

_ Php35,001 above

10. Level of Education you are currently teaching?

Elementary

Junior High School

Senior High School

College

Graduate Program

Vocational

Others, please specify: 
11. Type of School where you are currently working?

Public School

Private Sectarian

Private Non-sectarian

State Universities and Colleges

Local Colleges and Universities

Others, please specify:

12. How long have you been working as a teacher?

This is my first year

1-2 years

3-5 years

6-10 years

11-15 years

16-20 years

21 years and above

Prefer not to say

\section{Distance Learning}

13. Which of the following statements best describe your experience with online teaching?

_ I have extensive experience with online teaching

I have some experience with online teaching

This is my first experience with online teaching

My school has not switched to online/distance learning

\section{Opinion on Distance Learning Education during COVID-19 crisis}

14. How confident are you to teach remotely during this pandemic?

$\begin{aligned} 5 & \text { Very Confident } \\ 4 & \text { Confident } \\ 3 & \text { Neutral } \\ 2 & \text { Not Confident } \\ 1 & \text { Not Very Confident }\end{aligned}$

15. How would you rate your school's performance to distance learning education in terms of the following? Kindly rate whether you strongly agree (4), agree (3), disagree (2), or strongly disagree (1) with the following statements.

\begin{tabular}{|l|l|l|l|l|}
\hline \multicolumn{1}{|c|}{ Statements } & $\begin{array}{l}\text { Strongly } \\
\text { Agree }\end{array}$ & Agree & Disagree & $\begin{array}{l}\text { Strongly } \\
\text { Disagree }\end{array}$ \\
\hline $\begin{array}{l}\text { The school has provided capacity building } \\
\text { on distance learning education management } \\
\text { for teachers }\end{array}$ & & & & \\
\hline $\begin{array}{l}\text { The school has a designated workforce for } \\
\text { the COVID-19 }\end{array}$ & & & & \\
\hline $\begin{array}{l}\text { The school has provided the regulations and } \\
\text { policies on the use of distance learning to } \\
\text { protect student's identity and data privacy }\end{array}$ & & & & \\
\hline
\end{tabular}




\begin{tabular}{|l|l|l|l|l|}
\hline $\begin{array}{l}\text { The school has provided supplementary } \\
\text { materials for distance learning, such as } \\
\text { subscriptions to online libraries }\end{array}$ & & & & \\
\hline $\begin{array}{l}\text { The school has procured an online learning } \\
\text { management system }\end{array}$ & & & & \\
\hline $\begin{array}{l}\text { The school has a system of information } \\
\text { dissemination to communicate with the } \\
\text { parents and the learners during the CoVid- } \\
19 \text { outbreak. }\end{array}$ & & & & \\
\hline $\begin{array}{l}\text { The school provides a technical support } \\
\text { system to teachers }\end{array}$ & & & & \\
\hline $\begin{array}{l}\text { The school has a financial support system } \\
\text { for teachers }\end{array}$ & & & & \\
\hline $\begin{array}{l}\text { The school has an emotional support system } \\
\text { mechanism for teachers (ex. for managing } \\
\text { stress) }\end{array}$ & & & & \\
\hline $\begin{array}{l}\text { The school has provided a positive } \\
\text { environment for teachings during this crisis }\end{array}$ & & & & \\
\hline
\end{tabular}

\section{Problems encountered in Distance Learning Education}

16. Considering your experience in distance learning in the past weeks, which of the following challenges in switching to online/distance learning have you experienced?

\begin{tabular}{|c|c|c|c|c|c|c|c|}
\hline Statements & $\begin{array}{l}\text { Every } \\
\text { time }\end{array}$ & $\begin{array}{l}\text { Usually, in } \\
\text { about } 90 \% \\
\text { of the } \\
\text { chances, I } \\
\text { could have }\end{array}$ & $\begin{array}{l}\text { Frequently, } \\
\text { in about } \\
70 \% \text { of the } \\
\text { chances } \\
\text { when I } \\
\text { could have }\end{array}$ & $\begin{array}{l}\text { Sometimes } \\
\text {, in about } \\
50 \% \text { of the } \\
\text { chances } \\
\text { when I } \\
\text { could have }\end{array}$ & $\begin{array}{l}\text { Occasionall } \\
y, \text { in about } \\
30 \% \text { of the } \\
\text { chances } \\
\text { when I } \\
\text { could have }\end{array}$ & $\begin{array}{c}\text { Rarely, in } \\
\text { less than } \\
10 \% \text { of the } \\
\text { chances } \\
\text { when I } \\
\text { could have }\end{array}$ & Never \\
\hline $\begin{array}{l}\text { Access to stable internet } \\
\text { connection }\end{array}$ & & & & & & & \\
\hline $\begin{array}{l}\text { Teachers' access to } \\
\text { technology }\end{array}$ & & & & & & & \\
\hline $\begin{array}{l}\text { Adapting to distance } \\
\text { learning } \\
\text { teaching/learning } \\
\text { practices }\end{array}$ & & & & & & & \\
\hline $\begin{array}{l}\text { Using information and } \\
\text { communication } \\
\text { technologies }\end{array}$ & & & & & & & \\
\hline $\begin{array}{l}\text { Using the school's } \\
\text { learning management } \\
\text { systems (LMS) }\end{array}$ & & & & & & & \\
\hline $\begin{array}{l}\text { Interacting/Communicat } \\
\text { ng with students }\end{array}$ & & & & & & & \\
\hline $\begin{array}{l}\text { Involving students from } \\
\text { socially disadvantaged } \\
\text { homes }\end{array}$ & & & & & & & \\
\hline $\begin{array}{l}\text { Evaluating the learners' } \\
\text { knowledge and skills }\end{array}$ & & & & & & & \\
\hline
\end{tabular}




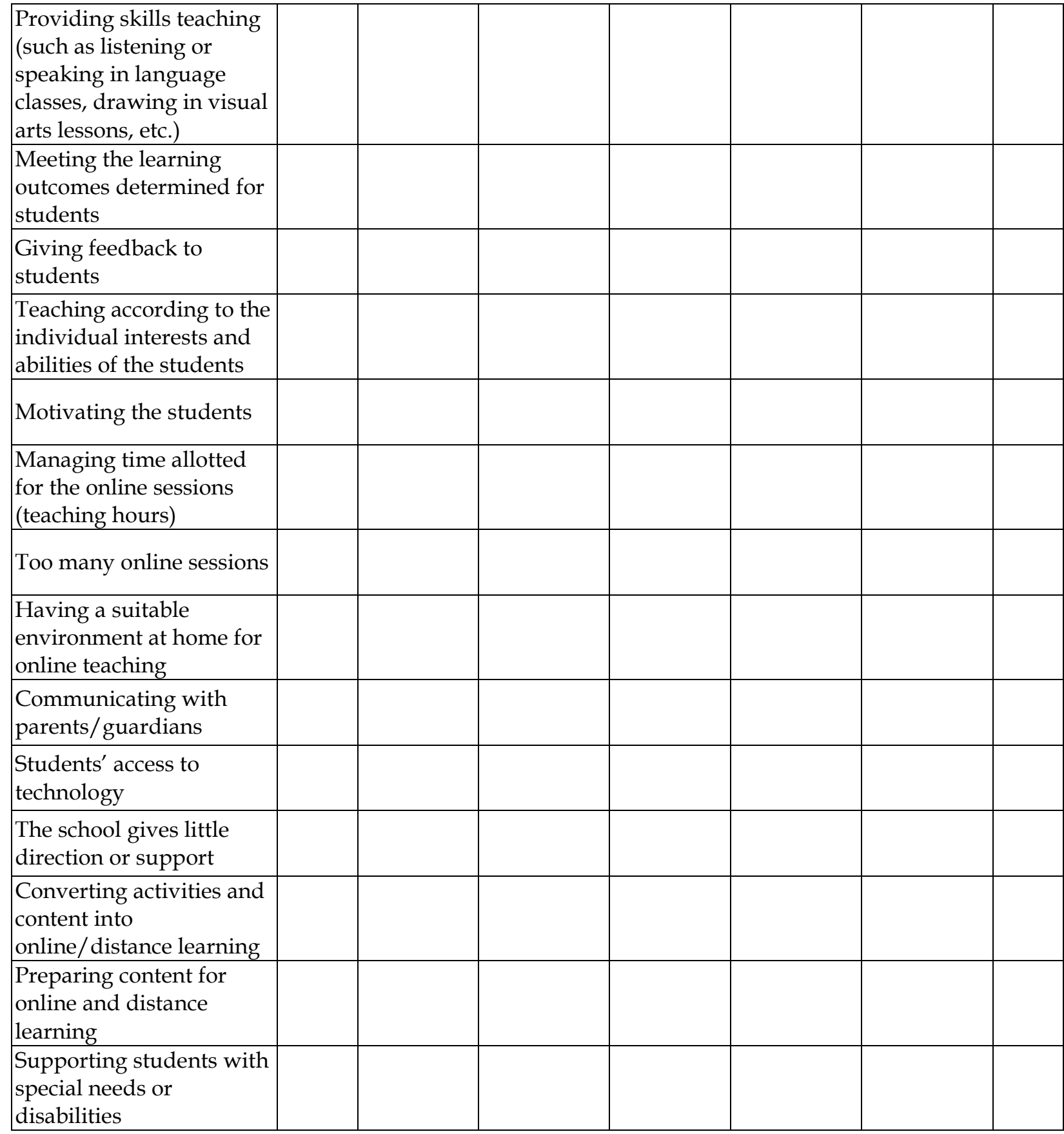

\section{Distance Learning Education Support Needed}

17. What would most help you to support online learning during the school closure? Kindly rate whether you strongly agree (4), agree (3), disagree (2), or strongly disagree (1) with the following statements.

\begin{tabular}{|l|l|l|l|l|}
\hline \multicolumn{1}{|c|}{ Statements } & $\begin{array}{c}\text { Strongly } \\
\text { Agree }\end{array}$ & Agree & Disagree & $\begin{array}{c}\text { Strongly } \\
\text { Disagree }\end{array}$ \\
\hline $\begin{array}{l}\text { Professional development: quick } \\
\text { courses on online teaching }\end{array}$ & & & & \\
\hline $\begin{array}{l}\text { Easy contact with experts (e.g., } \\
\text { experienced online-learning teacher, } \\
\text { ICT expert }\end{array}$ & & & & \\
\hline
\end{tabular}




\begin{tabular}{|l|l|l|l|l|}
\hline $\begin{array}{l}\text { Clear guidance from the Department } \\
\text { of Education }\end{array}$ & & & & \\
\hline $\begin{array}{l}\text { Websites with lists of valuable } \\
\text { resources }\end{array}$ & & & & \\
\hline Video clips of good practices & & & & \\
\hline Lesson plans of good practices & & & & \\
\hline $\begin{array}{l}\text { More educational TV programs by } \\
\text { national media organizations }\end{array}$ & & & & \\
\hline $\begin{array}{l}\text { More free resources and tools from } \\
\text { education technology companies or } \\
\text { organizations }\end{array}$ & & & & \\
\hline $\begin{array}{l}\text { Webinars for teachers to share ideas } \\
\text { and challenges }\end{array}$ & & & & \\
\hline
\end{tabular}

Thank you for participating in this survey. Rest assured that we will adhere to the strictest confidentiality requirements and no personal information will be released nor used outside this study. 